\title{
Responses of mixed light-emitting diode ratios on vegetative, flower regulation, and stalk elongation of cut chrysanthemum (Dendranthema grandiflora Tzvelev)
}

\author{
Ganesh S* \\ Department of Floriculture and Landscape Architecture, Horticultural College \& Research \\ Institute, Tamil Nadu Agricultural University, Coimbatore - 641003 (Tamil Nadu), India. \\ Jawaharlal M \\ Directorate of Extension Education, Tamil Nadu Agricultural University, Coimbatore - 641003 \\ (Tamil Nadu), India. \\ Rajamani K \\ Department of Floriculture and Landscape Architecture, Horticultural College \& Research \\ Institute, Tamil Nadu Agricultural University, Coimbatore - 641003 (Tamil Nadu), India \\ Thamaraiselvi SP \\ Department of Floriculture and Landscape Architecture, Horticultural College \& Research \\ Institute, Tamil Nadu Agricultural University, Coimbatore - 641003 (Tamil Nadu), India \\ *Corresponding author. Email: ganes4u@gmail.com
}

\section{Article Info}

https://doi.org/10.31018/ jans.v13i2.2636

Received: March 13, 2021

Revised: May 12, 2021

Accepted: May 15, 2021

\section{How to Cite}

Ganesh, S. et al. (2021). Responses of mixed light-emitting diode ratios on vegetative, flower regulation, and stalk elongation of cut chrysanthemum (Dendranthema grandiflora Tzvelev). Journal of Applied and Natural Science, 13(2), 496 - 503. https:// doi.org/10.31018/jans.v13i2.2636

\begin{abstract}
A Greenhouse experiment on the study of responses of mixed light-emitting diode ratios in cut chrysanthemum (Dendranthema grandiflora Tzvelev) was conducted at the Department of Floriculture and Landscape Architecture, Tamil Nadu Agricultural University, Coimbatore during 2019-20. The experiment was laid out in Randomized Block Design with three replications. The treatment comprises of seven varied light-emitting diode irradiance levels viz., $L_{1}-100 \%$ White; $L_{2}-100 \%$ Red; $L_{3}-80 \%$ Red $+20 \%$ Blue; $L_{4}-80 \%$ Red $+20 \%$ Far-red; $L_{5}-75 \%$ Blue $+25 \%$ Far-red; $L_{6}-60 \%$ Red $+20 \%$ Blue $+20 \%$ Far-red; $L_{7}-$ High pressure sodium vapour lamp (as check) in Salvador and Pusa Centenary varieties. The results revealed that the growth in terms of height of the chrysanthemum at critical stages was maximum (48.88 cm in Salvador and $41.92 \mathrm{~cm}$ in Pusa Centenary) under the light irradiance of $\mathrm{B}_{75} \mathrm{FR}_{25}\left(\mathrm{~L}_{5}\right)$ during the peak vegetative stage and registered maximum leaf area. Highest internodal length up to $3^{\text {rd }}$ leaf of $1.07 \mathrm{~cm}$ was registered in sodium vapour lamp irradiance $\left(L_{7}\right)$ and $1.39 \mathrm{~cm}$ in $100 \%$ Red irradiance $\left(L_{2}\right)$. The early flower bud emergence (39 days in Salvador and 50 days in Pusa Centenary) was observed in $\mathrm{B}_{55} \mathrm{Fr}_{25} \mathrm{spectral}_{\mathrm{irradi}}$ ance $\left(L_{5}\right)$. The highest total cut stem yield per square meter (42.65 in Salvador and 41.99 in Pusa Centenary) was registered in $R_{80} B_{20}$. The study revealed that blue LEDs combined with Far-red promoted early flowering and inhibited stem elongations. Red and Blue wavelength increased the total leaf area and registered improved flower yield.
\end{abstract}

Keywords: Chrysanthemum, Flower regulation, Flower stalk elongation, Light-emitting diodes, Mixed RBFr irradiance

\section{INTRODUCTION}

Chrysanthemum (Dendranthema grandiflora Tzvelev), the critical short day plant is the third most important cut flower in the international trade that requires a long night for flowering. Normally chrysanthemums are retained vegetatively at $14 \mathrm{hrs}$ of LD and $10 \mathrm{hrs}$ of SD and promoted flowering at 10/14 hrs of photoperiod. Under greenhouses, the day length can be altered by the installation of supplemental lighting systems, so that the plants will attain the standard quality and also ensures off-season availability of flowers (Thakur and Grewal, 2016). The supplemental lighting also enables year-round flower production by an enhanced photosynthetic process that drives growth and production. In India, cut chrysanthemums are mostly grown in states like Karnataka, Maharashtra, Tamil Nadu, Himachal Pradesh, Punjab, Uttar Pradesh, West Bengal, etc. In Tamil Nadu, chrysanthemum cultivation under greenhouses is only about 8.0 ha at present (2019-20). To- 
day, although there are over 8 lakhs of stem demand per week, the production of chrysanthemums is hardly $10 \%$ of the demand. The supply of chrysanthemum is far less than the demand and there is scope for production under a protected environment.

The management of photoperiod for its successful cultivation is a prerequisite and challenging too. As indicated above, the alteration of photoperiodic duration involves the installation of energy-efficient lighting systems inside the greenhouse. Lighting is an energyconsuming process, the installation of high-intensity discharge lamps (HIDs), incandescent lamps and metal halide lamps for day extending (DE)/supplemental lighting consume more power which results in additional cost in electricity itself. Recent development in LED technology creates new opportunities for low and highintensity lighting of greenhouse crops. The integration of LEDs in current growing systems receives full attention as they provide the opportunity to control the light spectrum. LEDs are compared to conventional HIDs on the induction of target plant responses such as photosynthetic, photoperiodic, and photomorphogenic, respectively. The combination of different regimens of LEDs can provide improved influence and customized wavelengths for flower cultivation (Monostori et al., 2018). Mixed red and blue light may improve photosynthetic activity and regulate morphogenesis (Shen et al., 2014). The spectral quality effects have an influence on the plant biometric responses and flower value. Literature revealed that the light quality rich in Red Light $(R)$ relative to Far-Red (F/R) could suppress elongation growth, make plants shorter (Paradiso and Proietti, 2021). On the contrary, light quality relatively rich in Far-Red promotes extension growth, making plants taller and leaf expansion (Zheng et al. 2019). An interesting fact that in LEDs, more energy is converted into usable light for photosynthesis or photomorphogenic effects. Red (R) and Blue light (B) enhance photosynthetic metabolism. These are the light sources to provide the capability of true spectral composition control, allowing wavelength to match to plant photoreceptors to optimize production as well as to influence plant morphology and composition. However, the use of LEDs during greenhouse cultivation is rather new and has great potential both from a commercial research point of view. Studies have shown that by increasing canopy photon capture efficiency and/or precisely controlling light output in response to the environment or certain physiological parameters, energy efficiency and plant productivity can be optimized with LEDs (Gomez and Izzo, 2018). Hence, the above study was conducted to understand the spectral quality effects of LEDs and to determine the appropriate colour ratios to regulate growth, flowering, and flower stalk length in the Salvador and Pusa Centenary varieties of chrysanthemum.

\section{MATERIALS AND METHODS}

\section{Study area and planting materials}

The study was carried out in the aerodynamic polyhouse located at the Department of Floriculture and Landscape Architecture, during the period 2019-20. The polyhouse is geographically located in the Coimbatore district at 11002 " N Latitude, 760 57" E Longitude, and $426.76 \mathrm{~m}$ above MSL altitude. The Chrysanthemum varieties "Salvador" supplied by M/s. FLORITEC Breeding by Design, Dutch, and "Pusa Centenary" by Indian Agricultural Research Institute, New Delhi was used in the study. The field was ploughed well and the soils are made into fine tilth and till become powdery. Beds of $12 \times 1.0 \mathrm{~m}^{2}$ size were prepared to a height of $45 \mathrm{~cm}$ and width $(40 \mathrm{~cm})$ was left as the walking path between the beds. The bed was then dug up to 15-20 $\mathrm{cm}$ and weeds and debris were removed. A bed was then raised to $45 \mathrm{~cm}$ above ground level. The soil medium was enriched with $3 \mathrm{~kg} / \mathrm{m}^{2}$ of composted coir, 500 $\mathrm{g} / \mathrm{m}^{2}$ of vermicompost, $10 \mathrm{~kg} / \mathrm{m}^{2}$ of well-decomposed farmyard manure, and microbial consortia (Azospirillum, Phosphobacteria, and VAM) @ $50 \mathrm{~g}$ each $/ \mathrm{m}^{2}$. The field is then leveled and watered well. The terminal rooted cuttings were then transplanted in the main field at a spacing of $15 \mathrm{~cm} \times 15 \mathrm{~cm}$, accommodating 44 plants per sq.m. Nine plants in the center of the plot in each replication were chosen for recording observations. The cultural operations were followed as per the recommendation from the Tamil Nadu Agricultural University Horticultural Crop Production Guide (2020).

\section{Treatment details}

The experiment was laid in Randomized Block Design with three replications. In the experiment, chrysanthemum plants were exposed to LEDs for $4 \mathrm{hr}$ duration (as supplemental lighting) and $4 \mathrm{hr}$ (check) with sodium vapour lamp as long-day exposure. Different wavelengths composed of white (W), Blue (B), Red (R), and Far-red (FR) light-emitting diodes at $4 \mathrm{hr}$ each exposed with white (1900 lumens); R (41 $\mu \mathrm{mol} / \mathrm{J}) ; \operatorname{BFr}(37 \mu \mathrm{mol} /$ $\mathrm{J}) ; \operatorname{RB}(43 \mu \mathrm{mol} / \mathrm{J}) ; \operatorname{RFr}(41 \mu \mathrm{mol} / \mathrm{J}) ; \operatorname{RBFr}(43 \mu \mathrm{mol} / \mathrm{J})$ and control with HPS lamp for $4 \mathrm{hr}(725 \mu \mathrm{mol} / \mathrm{s}$ or $\mathrm{J})$ were irradiated to the plants. The treatments comprised of $L_{1}-100 \%$ White (380 to $740 \mathrm{~nm}$ ); $L_{2}-100 \% \operatorname{Red}(625$ to $700 \mathrm{~nm}) ; \mathrm{L}_{3}-80 \%$ Red+ $20 \%$ Blue; $\mathrm{L}_{4}-80 \%$ Red + $20 \%$ Far-red (700 to $850 \mathrm{~nm}$ ); $\mathrm{L}_{5^{-}} \mathbf{7 5} \%$ Blue $+25 \%$ Farred (445 to $850 \mathrm{~nm}$ ); $\mathrm{L}_{6}-60 \%$ Red $+20 \%$ Blue $+20 \%$ Far-red (445 to $850 \mathrm{~nm}$ ); $\mathrm{L}_{7}$ - Sodium vapour lamp (check).

\section{Assessment of morphophysiological and yield parameters}

The plant morphological parameters were recorded at three critical stages of chrysanthemum viz., peak vege- 
tative stage, bud appearance stage, and peak flowering stage. Nine plants in each treatment were selected at random and tagged for observations on different traits. The mean of nine plants is taken into account. The height of the plant was measured from the base of the plant to the terminal tip at the critical stages and was expressed in centimeters (cms). The internodal length was also recorded by using length between $3^{\text {rd }}, 4^{\text {th }}$ and $5^{\text {th }}$ internodes from the tip, and the mean was expressed in centimeter $(\mathrm{cm})$. The total leaf area was calculated by multiplying the length $(\mathrm{cm})$ and breadth $(\mathrm{cm})$ of the leaf with the constant ' $\mathrm{K}$ ' factor (0.646) and a number of green leaves and expressed in square centimeter $\left(\mathrm{cm}^{2}\right)$. Light interception percent was the ratio of a difference between light intensity in the open canopy and average light intensity at the middle of the canopy and ground level (Charles Edwards, 1982). Light Transmission Ratio was the ratio of light intensity at the ground surface and light intensity above the canopy (Subburamu and Ravichandran, 2009)

\section{Statistical analysis}

Experimental data is statistically analyzed as suggested by Panse and Sukhatme (2000). The critical differences were worked out for $5 \%(0.05)$ and $1 \%(0.01)$ probability. The treatment differences that were not significant were denoted by "NS".

\section{RESULTS AND DISCUSSION}

\section{Influence of light emitting diodes on growth attributes of Chrysanthemum (D. grandiflora Tzvelev)}

Significant differences were observed for plant height of chrysanthemum varieties of Salvador and Pusa Centenary at critical stages viz., peak vegetative stage, bud appearance stage and flowering stage when exposed to different light treatments (Table 1). The plant height was maximum under the light combinations of $75 \%$ Blue $+25 \%$ Far-red $\left(L_{5}\right)$ at the peak vegetative stage in both Salvador $(48.88 \mathrm{~cm})$ and Pusa Centenary (41.92 $\mathrm{cm}$ ) of Chryanthemum. Plants grown under the mixture of $75 \%$ blue and $25 \%$ Far-red registered a significantly $(p<0.05$ and $p<0.01$ respectively) higher plant height at the initial stages of plant development than other light combinations. But during the bud appearance and flowering stage, plants grown under $80 \%$ red $+20 \%$ blue LEDs $\left(L_{3}\right)$ have registered the highest plant height (85.33 cm \& $112.52 \mathrm{~cm}$ in Salvador; $62.94 \mathrm{~cm}$ \& 116.81 $\mathrm{cm}$ in Pusa Centenary). Blue light has inhibited stem elongations at the later stage of growth. Reduction in growth attributed to the shorter leaf length and width ultimately the reduction in leaf area. The results are in accordance with the findings of Oyaert et al. (1999) in Chrysanthemum (Dendranthem $x$ grandiflorum cV White Reagan) and Lee et al. (2011) in Paphiopedilum cv 'Hsingying Carlos'. The growth promotion in $80 \%$ $\mathrm{R}: 20 \% \mathrm{~B}$ spectral combinations might be attributed to the delay in conversion of Pr to Pfr phytochromes. Phytochromes regulated the stem elongation and leaf expansion (Urrestarazu et al. 2018). The dichromatic spectral distributions at the canopy level might have increased the photosynthetic rate and stomatal size in the leaves (Kim et al. 2004 \& Bantis et al. 2018 in Chrysanthemum (D. grandiflorum Kitam 'Cheonsu'). The present findings revealed that at certain stage, the plants which received $\mathrm{B}_{75} \mathrm{Fr}_{25}$ had stopped the growth and transforms its growth from vegetative to generative stage in both Salvador and Pusa Centenary varieties of Chrysantemum (D. grandiflora Tzvelev). This property of spectral distribution might have useful in the growing chrysanthemums for ornamental purpose especially the pot mums. The earliness or premature flowering was noticed at Blue: Far-red combinations. Urrestarazu et al. 2018 opined that high Far-red/ Red irradiation caused premature flowering in many species and elongated stems and petioles. Zhen and van lersel (2017) have reported that an increase of Far-red ratio in a fixture have constantly increased the net photosynthetic rate in lettuce (Lactuca sativa 'Green Towers'). However, no differences were observed in the control plot $L_{7}$ $\left(\mathrm{R}_{60} \mathrm{~B}_{20} \mathrm{Fr}_{20}\right)$ in both Chrysanthemum varieties viz. Salvador and Pusa Centenary.

The mixed wavelength of LEDs has significantly affected the internodal elongation in both varieties of chrysanthemum. The internodal length at the $3^{\text {rd }}$ leaf stage and after the $3^{\text {rd }}$ leaf stage showed significant variance ( $p<0.05$ and $p<0.01$ respectively) (Table 2$)$. Internodal length in Chrysanthemum varieties was also highest in mixed lights containing Blue wavelength $(1.07 \mathrm{~cm}, 1.03$ $\mathrm{cm}$ ) in Salvador which have influenced the height of the plants receiving Blue LED irradiance for 4-hour extended lighting. The increased internode light is attributed to the increased light distribution within the plant canopy enabling the greater light absorbtion ( The lowest internode length was registered in $100 \%$ White light irradiance. In contrary to the above results, several workers have reported that Blue light inhibited the internode elongation and also indicated that plants have many Blue light receptors such as cryptochromes might have regulated the plant growth and flowering of marigold (Tagetes erecta L. cv. Orange Boy \& Salvia (Salvia splendens F. Sello ex Ruem \& Schult (Heo et al. 2002) and Chrysanthemum morifolium cv. Radost (Sharathkumar et al. 2021). It is also reported that acceleration of stem elongation rate in extended daylights is caused by the depression of blue lights in Datura ferox L. and Sinapis alba L. (Ballare et al. 1991). In Pusa Centenary, the perception of blue light by the leaves is also important, which influences the perception of R: FR $\left(L_{4}\right)$ by the internodes. In the present study, it is observed that number of internodes was 
Ganesh, S. et al. / J. Appl. \& Nat. Sci. 13(2), 496 - 503 (2021)

Table 1. Effect of light irradiance on plant height $(\mathrm{cm})$ of $D$. grandiflora Tzvelev at critical stages.

\begin{tabular}{|c|c|c|c|c|c|c|}
\hline \multirow{3}{*}{$\begin{array}{l}\text { Light irradiance } \\
\text { (L) }\end{array}$} & \multicolumn{6}{|c|}{ Plant height at growth stages $(\mathrm{cm})$} \\
\hline & \multicolumn{3}{|c|}{ Salvador (G) } & \multicolumn{3}{|c|}{ Pusa Centenary (G) } \\
\hline & $\begin{array}{l}\text { Peak } \\
\text { vegetative } \\
\text { stage }\end{array}$ & $\begin{array}{l}\text { Bud } \\
\text { appearance } \\
\text { stage }\end{array}$ & $\begin{array}{l}\text { Flowering } \\
\text { stage }\end{array}$ & $\begin{array}{l}\text { Peak } \\
\text { vegetative } \\
\text { stage }\end{array}$ & $\begin{array}{l}\text { Bud } \\
\text { appearance } \\
\text { stage }\end{array}$ & $\begin{array}{l}\text { Flowering } \\
\text { stage }\end{array}$ \\
\hline$\overline{\mathrm{L} 1}$ & 43.44 & 82.22 & 111.50 & 40.86 & 66.22 & 108.11 \\
\hline L2 & 42.27 & 75.09 & 88.42 & 39.50 & 65.39 & 104.73 \\
\hline L3 & 45.02 & 85.33 & 112.52 & 29.88 & 62.94 & 116.81 \\
\hline L4 & 43.69 & 78.67 & 101.45 & 40.99 & 69.11 & 94.95 \\
\hline L5 & 48.88 & 68.22 & 71.05 & 41.92 & 67.39 & 71.00 \\
\hline L6 & 43.67 & 71.33 & 109.62 & 40.38 & 69.51 & 99.77 \\
\hline L7 & 39.57 & 70.83 & 102.34 & 33.95 & 65.72 & 109.94 \\
\hline Mean & 43.79 & 75.96 & 99.56 & 38.21 & 66.61 & 100.76 \\
\hline S.Em & 1.4519 & 3.2778 & 1.484 & 2.915 & 5.4493 & 1.6021 \\
\hline SED & 2.0533 & 4.6355 & 2.0987 & 4.122 & 7.7065 & 2.2658 \\
\hline$C D(p=0.05)$ & 4.4737 & 10.0910 & 4.5727 & 8.9821 & 16.791 & 4.9367 \\
\hline$C D(p=0.01)$ & 6.2718 & 14.1592 & 6.4105 & 12.592 & 23.540 & 6.9201 \\
\hline
\end{tabular}

L1 - 100\% White (380 to $740 \mathrm{~nm}$ ); L2 - 100\% Red (625 to $700 \mathrm{~nm}$ ); L3 - 80\% Red + 20\% Blue; L4 - 80\% Red + $20 \%$ Far-red (700 to $850 \mathrm{~nm}$ ); L5 - 75\% Blue + 25\% Far-red (445 nm to 850nm); L6 - 60\% Red + 20\% Blue + 20\% Far-red (445 to $850 \mathrm{~nm}$ ); L7 - Sodium vapour lamp (check)

Table 2. Effect of light irradiance on internodal length up to $3^{\text {rd }}$ leaf and after $3^{\text {rd }}$ leaf $\left(\mathrm{cm}^{2}\right)$ of $D$. grandiflora Tzvelev.

\begin{tabular}{|c|c|c|c|c|}
\hline \multirow[b]{2}{*}{ Light irradiance (L) } & \multicolumn{2}{|c|}{ Salvador (G) } & \multicolumn{2}{|c|}{ Pusa Centenary (G) } \\
\hline & $\begin{array}{l}\text { Internodal length (up } \\
\text { to } 3^{\text {rd }} \text { leaf) } \\
\text { (cm) }\end{array}$ & $\begin{array}{l}\text { Internodal length } \\
\text { (after } 3^{\text {rd }} \text { leaf) } \\
\text { (cm) }\end{array}$ & $\begin{array}{l}\text { Internodal length } \\
\text { (up to } 3^{\text {rd }} \text { leaf) } \\
\text { (cm) }\end{array}$ & $\begin{array}{l}\text { Internodal length } \\
\text { (after } 3^{\text {rd }} \text { leaf) } \\
\text { (cm) }\end{array}$ \\
\hline L1 & 0.92 & 2.33 & 1.00 & 2.12 \\
\hline L2 & 0.93 & 2.25 & 0.95 & 1.39 \\
\hline L3 & 0.97 & 2.64 & 0.87 & 1.85 \\
\hline L4 & 0.93 & 2.16 & 1.39 & 2.22 \\
\hline L5 & 1.03 & 2.33 & 1.11 & 2.33 \\
\hline L6 & 0.99 & 2.18 & 1.08 & 1.98 \\
\hline L7 & 1.07 & 1.92 & 0.83 & 2.13 \\
\hline Mean & 0.98 & 2.60 & 1.03 & 2.01 \\
\hline S.Em & 0.1017 & 0.1180 & 0.2081 & 0.1024 \\
\hline S.ED & 0.1439 & 0.1669 & 0.2943 & 0.1448 \\
\hline$C D(p=0.05)$ & 0.3135 & 0.3637 & 0.6413 & 0.3154 \\
\hline$C D(p=0.01)$ & 0.4395 & 0.5099 & 0.8991 & 0.4422 \\
\hline
\end{tabular}

L1 - 100\% White (380 to $740 \mathrm{~nm}$ ); L2 - 100\% Red (625 to $700 \mathrm{~nm}$ ); L3 - 80\% Red + 20\% Blue; L4 - 80\% Red + $20 \%$ Far-red (700 to $850 \mathrm{~nm}$ ); L5 - 75\% Blue + 25\% Far-red (445 nm to 850nm); L6 - 60\% Red + 20\% Blue + 20\% Far-red (445 to $850 \mathrm{~nm}$ ); L7 - Sodium vapour lamp (check)

lesser in the blue light irradiated plants. The number of internodes was inversely proportional to the length of internodes of Sinapis alba L. (Casal and Smith, 1988; Demotes-Mainard et al., 2016).

\section{Total leaf area per plant}

The study revealed that there were significant differences among the chrysanthemum varieties in different spectral ranges for the total leaf area of chrysanthemum plants. Leaf area is an essential trait to assess the significance of light in terms of photosynthesis.
Maximum leaf area was observed in both the genotypes under mixed Red $80 \%+20 \%$ Blue light, while the minimum leaf area was registered in $80 \%$ Red $+20 \%$ Far-Red in Salvador and $\left(L_{1}\right) 100 \%$ white light in Pusa Centenary (Fig 1). The highest leaf area might be due to an increase in net photosynthetic rate under $\mathrm{RB}$ radiated zones while low under BF and sodium vapour lamp radiated plantlets. Increased total leaf area was observed in the seedlings of begonia, geranium, petunia, and antirrhinum when grown under $100 \%$ Mint White LEDs (MW100) (Park and Runkle, 2018). This is 
likely because red-blue extension received a higher PPFD of $241.67 \mu \mathrm{molm}^{-2} \mathrm{~s}^{-1}$ and $294.00 \mu_{\mathrm{molm}}{ }^{-2} \mathrm{~s}^{-1}$ compared to $77.67 \mu \mathrm{molm}^{-2} \mathrm{~s}^{-1}$ and $135 \mu \mathrm{molm}^{-2} \mathrm{~s}^{-1}$ under $4 \mathrm{~h}$ of sodium vapour lamp irradiance extension. The results are in accordance with SharathKumar et al. (2021) when the C. morifolium cv. Radost plants were grown under $15 \mathrm{~h}$ long-day solar photoperiod. Li et al. (2020) opined that the leaf area was high in RB, which suggested that the light spectrum was optimum and promotion of whole plant development and increased photosynthesis by increasing $\mathrm{Chl}$ a and total Chl contents in seedlings of Sweet Pepper (Capsicum annum L.). Ouzounis et al. (2014) also found that in C. morofolium 'Coral Charm' and Campanula portenschlagiana 'BlueOne', 20\%B + 80\%R showed the highest leaf area expansion. In contrast, the reduction in leaf area at $80 \%$ R:20\%B LED radiation was registered in Rosa $x$ hybrida cv. Toril (Terfa et al., 2013). Reduction in leaf area is attributed to the application of blue lights inhibits cell division and cell expansion (Bugbee, 2017). The increasing trend in the total leaf area of chrysanthemum variety Salvador and Pusa Centenary was registered at the respective critical stages of chrysanthemum (D. grandiflora Tzvelev).

\section{Influence of LEDs on flower attributes of Chrysan- themum (D. grandiflora Tzvelev)}

Acceleration in flowering is observed in many flower crops under low R: Fr ratios. Several traits involved in photosynthesis are regulated by phyB and $R$ and $F R$ lights. The earliness in flower bud emergence (39 days in Salvador and 50 days in Pusa Centenary) was ob- served in $75 \%$ Blue $+25 \%$ Far-red at $445 \mathrm{~nm}$ to $850 \mathrm{~nm}$ spectral irradiance $\left(L_{5}\right)$ followed by $L_{3}\left(R_{80} B_{20}\right)$ (Table 3 ). The result has implied the negative effects of $B$ and BFr on the growth and photosynthesis of chrysanthemum and this might be due to the inhibitory effect of blue light on stalk growth. The findings are concomitant with Kim et al. (2004). Mortensen and Stromme (1987) also observed inhibition of stalk growth under blue irradiance in many greenhouse horticultural crops.

Supplemental lighting in greenhouse cultivation is proven to increase the growth and quality of flowers and ornamentals (Zheng and Van Labeke, 2017). The monochromatic or mixed Red/Blue/Far-red LEDs had different influences on the flowering and yield parameters. The flowering parameters are significantly increased in $80 \%$ Red $+20 \%$ Blue $\left(L_{3}\right)$ LED irradiated plants. The highest stalk length was recorded under mixed $\mathrm{R}$ and $\mathrm{B}$ but stalk growth was delicate due to the increased internodal length after the third leaf or third node (almost double the length up to $3^{\text {rd }}$ leaf). Under Monochromatic $\mathrm{R}$ and $\mathrm{RBFr}$, indifferent to mixed $\mathrm{R}$ and $B$, the internodal length up to the third leaf and after the third leaf was lesser.

Total cut stem yield per square meter (42.65 and 41.99) was highest in $80 \% \mathrm{R}: 20 \% \mathrm{~B}$ than other spectral ranges in Salvador and Pusa Centenary varieties (Table 4). The difference in light quality has influenced the duration of the blooming period (Heo et al. 2002). In the present study, the increase in yield might be due to light quality, which influenced the plant dry mass accumulation by altering leaf expansion and affected photosynthesis. This process promotes biomass accumulation by increasing photosynthetic carbon

Table 3. Effect of light irradiance on days to first flower bud appearance, days to first harvest and number of flower buds of $D$. grandiflora Tzvelev.

\begin{tabular}{lllllll}
\hline $\begin{array}{l}\text { Light } \\
\text { irradiance } \\
\text { (L) }\end{array}$ & \begin{tabular}{l} 
Salvador (G) \\
\cline { 2 - 7 } \\
flower bud \\
appearance
\end{tabular} & $\begin{array}{l}\text { Days to the } \\
\text { first harvest }\end{array}$ & $\begin{array}{l}\text { Number of } \\
\text { flower buds }\end{array}$ & $\begin{array}{l}\text { Days to first } \\
\text { flower bud } \\
\text { appearance }\end{array}$ & $\begin{array}{l}\text { Days to the } \\
\text { first harvest }\end{array}$ & $\begin{array}{l}\text { Number of } \\
\text { flower } \\
\text { buds }\end{array}$ \\
\hline L1 & 80.11 & 138.95 & 8.46 & 70.22 & 135.01 & 13.56 \\
L2 & 67.56 & 145.07 & 12.26 & 67.22 & 148.93 & 12.84 \\
L3 & 65.29 & 132.59 & 13.60 & 64.11 & 136.32 & 15.54 \\
L4 & 70.33 & 148.22 & 11.00 & 68.22 & 155.68 & 13.44 \\
L5 & 39.00 & 65.11 & 8.33 & 50.00 & 80.56 & 8.12 \\
L6 & 72.67 & 139.36 & 10.33 & 75.78 & 140.99 & 21.22 \\
L7 & 66.11 & 135.29 & 11.11 & 72.44 & 139.87 & 12.22 \\
Mean & 65.87 & 129.23 & 10.73 & 66.86 & 133.91 & 13.85 \\
S.Em & 1.7339 & 0.4395 & 0.6713 & 2.2485 & 0.3762 & 0.7775 \\
S.ED & 2.4521 & 0.6216 & 0.9494 & 3.1798 & 0.5320 & 1.0996 \\
CD $(p=0.05)$ & 5.3428 & 1.3543 & 2.0685 & 6.9282 & 1.1591 & 2.3958 \\
CD $(p=0.01)$ & 7.4902 & 1.8987 & 2.8998 & 9.7128 & 1.6249 & 3.3587 \\
\hline
\end{tabular}

L1 - 100\% White (380 to $740 \mathrm{~nm}$ ); L2 - 100\% Red (625 to $700 \mathrm{~nm}$ ); L3 - 80\% Red + 20\% Blue; L4 - 80\% Red + 20\% Far-red (700 to $850 \mathrm{~nm}$ ); L5 - 75\% Blue + 25\% Far-red (445 nm to 850nm); L6 - 60\% Red + 20\% Blue + 20\% Far-red (445 to $850 \mathrm{nm);} \mathrm{L7} \mathrm{-} \mathrm{Sodium}$ vapour lamp (check) 


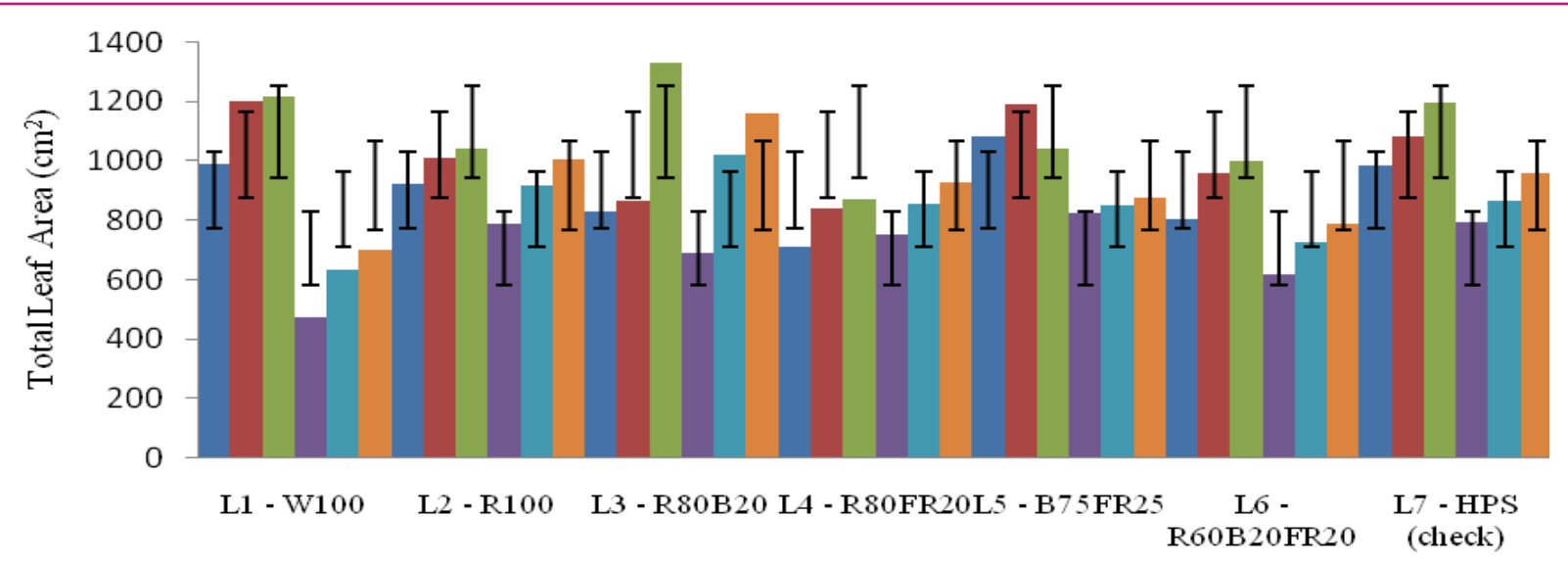

Light Irradiance

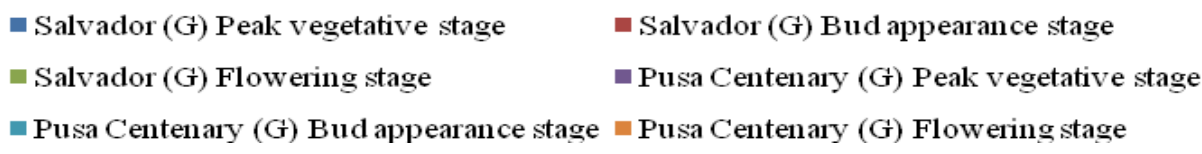

Fig. 1. Effect of light irradiance on total leaf area per plant (sq.cm) at critical stages

assimilation. An admixture of Red and Blue light sources may combine the advantages of monochromatic Red and monochromatic Blue and such activity may overcome the individual advantages of these lights. Similar findings were also reported by Surendra Singh Chauhan (2017) in Chrysanthemum cv Zembla and Thai Chen Queen; García-Caparrós et al. (2020); in Inch (Tradescantia zebrina) and Spider plant (Chlorophytum comosum); Choi et al. (2018) in Chrysanthemum cv Baekma and Jinba.
The present study showed that in Salvador variety, the spectral composition of $75 \%$ Blue $+25 \%$ Far-red $\left(L_{5}\right)$ combination has influenced the peduncle length (18.35 $\mathrm{cm})$ followed by $L_{6}(16.45 \mathrm{~cm})$ and $L_{3}(15.29 \mathrm{~cm})$, which is on par with $L_{5}$. $L_{3}(80 \%$ Red $+20 \%$ Blue $)$ has recorded the highest total cut stem yield of 42.65 stems per sq.m (Table 4). These spectral ranges not only have increased the flower stalk quality and also have increased the number of marketable stems (i.e Grade A stems - 40.70). The data revealed that in comparison

Table 4. Effect of light irradiance on flower stalk length $(\mathrm{cm})$ and total cut stem yield $/ \mathrm{m}^{2}$ of $D$. grandiflora Tzvelev.

\begin{tabular}{|c|c|c|c|c|}
\hline \multirow{2}{*}{$\begin{array}{l}\text { Light irradiance } \\
\text { (L) }\end{array}$} & \multicolumn{2}{|c|}{ Salvador (G) } & \multicolumn{2}{|c|}{ Pusa Centenary (G) } \\
\hline & $\begin{array}{l}\text { Flower stalk length } \\
\text { (cm) }\end{array}$ & Total cut stem yield $/ \mathrm{m}^{2}$ & $\begin{array}{l}\text { Flower stalk length } \\
\text { (cm) }\end{array}$ & $\begin{array}{l}\text { Total cut stem } \\
\text { yield } / \mathrm{m}^{2}\end{array}$ \\
\hline L1 & 108.50 & 40.25 & 101.90 & 41.38 \\
\hline L2 & 86.65 & 37.46 & 100.62 & 34.12 \\
\hline L3 & 107.50 & 42.65 & 111.58 & 41.99 \\
\hline L4 & 99.85 & 38.47 & 90.23 & 36.09 \\
\hline L5 & 66.50 & 41.32 & 69.50 & 40.33 \\
\hline L6 & 104.78 & 42.08 & 96.00 & 40.17 \\
\hline L7 & 97.75 & 41.55 & 105.24 & 40.56 \\
\hline Mean & 95.93 & 40.54 & 96.44 & 39.23 \\
\hline S.Em & 0.2284 & 0.0295 & 0.2085 & 0.0450 \\
\hline S.ED & 0.3230 & 0.0417 & 0.2949 & 0.0636 \\
\hline$C D(p=0.05)$ & 0.7037 & 0.0908 & 0.6426 & 0.1387 \\
\hline$C D(p=0.01)$ & 0.9865 & 0.1272 & 0.9009 & 0.1944 \\
\hline
\end{tabular}

L1 - 100\% White (380 to $740 \mathrm{~nm}$ ); L2 - 100\% Red ( 625 to $700 \mathrm{~nm}$ ); L3 - 80\% Red + 20\% Blue; L4 - 80\% Red + $20 \%$ Far-red (700 to $850 \mathrm{~nm}$ ); L5 - 75\% Blue + 25\% Far-red (445 nm to $850 \mathrm{~nm})$; L6 - 60\% Red + 20\% Blue + 20\% Far-red (445 to $850 \mathrm{~nm}$ ); L7 - Sodium vapour lamp (check). 
with the varietal responses, the stalk length of Pusa Centenary was higher $(69.50 \mathrm{~cm})$ than Salvador $(66.50$ $\mathrm{cm})$. In both Salvador and Pusa Centenary varieties, the blue wavelength $(445 \mathrm{~nm}$ to $850 \mathrm{~nm})$ might affect the earlier transition of vegetaive to reproductive phase or flowering phase under $75 \%$ Blue $+25 \%$ Far-red irradiance, which promoted early flowering. Park and Jeong (2020) have also reported that blue light has influenced the early flower bud formation and ultimately, the flower yield also increased in Chrysanthemum (D. grandiflorum cv. Gaya Yellow).

On the whole, the study elaborately discussed the spectral quality of single spectral light emitting diodes and the combined effect of spectral irradiances in the Chrysanthemum varieties, viz Salvador and Pusa Centenary. The different spectral quality of light emitting diodes showed significantly $(p<0.05$ and $p<0.01)$ varied responses irrespective of varieties planted. The variations observed were consistently improved. Though the application of light emitting diodes in crop production gains importance a decade ago, several results were recommended with the studies conducted under indoor systems and under soilless conditions. The present attempt envisage the efficacy of light emitting diodes under defined wavelength for chrysanthemum growing in tropical conditions. The results obtained from the study have indicated that spectral irradiance of a single wavelength or in combination have a significant effect on photomorphology and flowering.

\section{Conclusion}

In the present investigation, significant differences were observed $(p<0.05$ and $p<0.01)$ among all the traits studied. The results of the experiment revealed that the growth in terms of the height of the chrysanthemum plants at critical stages was maximum $(48.88 \mathrm{~cm}$ and $41.92 \mathrm{~cm}$ ) under the light irradiance of $\mathrm{B}_{75} \mathrm{FR}_{25}\left(\mathrm{~L}_{5}\right)$ during the peak vegetative stage in both the Salvador and Pusa Centenary varieties of chrysanthemum and registered maximum leaf area. Internodal length of the varieties was also highest in mixed lights emitting Blue wavelength $(1.07 \mathrm{~cm}, 1.03 \mathrm{~cm})$ in Salvador under 4hour extended durations. The early flower bud emergence (39 days in Salvador and 50 days in Pusa Centenary) was observed in $75 \%$ Blue $+25 \%$ Far-red spectral irradiance $\left(L_{5}\right)$. The early flowering behaviour of the variety Salvador might be due to its photosensitive nature, while Pusa Centenary variety flowers a little later. The highest total cut stem yield per square meter (42.65 and 41.99) was registered in $\mathrm{R}_{80} \mathrm{~B}_{20}$. The study indicates the effect of different spectral ranges alone or in combination in the enhancement of growth and photosynthesis of chrysanthemum. The study promulgated that irradiance of single wavelength of different spectral ranges or combined wavelengths on improving the growth and yield of polyhouse chrysanthemums var Salvador and var Pusa Centenary. The results of the present study opined that there is uniformity in the growth of the plants at their critical stages, which envisaged that thers is a uniformity in the spectral quality and less heating effect at the plant canopy. The cost of cultivation of the experiment indicated that there is 66 $\%$ of the cost on electricity is saved which reflected on the increase of $16.21 \%$ of net income in a unit area. Also the effect of single wavelength on photomorphogenic characters of chrysanthemum plant is well established with improved total leaf area of the plant, stem girth, early flowering, flower yield and colour.

\section{ACKNOWLEDGEMENTS}

The authors thank Tamil Nadu Agricultural University (TNAU), Coimbatore, Tamil Nadu, India, for the financial support through the core research projects funded by the Government of Tamil Nadu and Department of Floriculture and Landscape Architecture, TNAU, for the conduct of the study.

\section{Conflict of interest}

The authors declare that they have no conflict of interest.

\section{REFERENCES}

1. Ballare, C.L., Scopel, A.L. \& Sanchez, R.A. (1991). Photocontrol of stem elongation in plant neighborhoods: effects of photon fluence rate under natural conditions of radiation. Plant Cell Environ, 14, 57-65.

2. Bantis, F., Smirnakou, S., Ouzounis, T., Koukounaras, A., Ntagkas, N. \& Radoglou, K. (2018). Current status and recent achievements in the field of horticulture with the use of light-emitting diodes (LEDs). Scientia Horticulturae, 235, 437-45.

3. Bugbee B. (2017). Economics of LED Lighting. Light Emitting Diodes for Agriculture: Smart Lighting, First ed.; Datta Gupta, S. Springer Publications: Springer Nature Singapore Pte Ltd, India, 81-99.

4. Casal, J. J. \& Smith, H. (1988). The loci of perception for phytochrome control of internode growth in light-grown mustard: Promotion by low phytochromephotoequilibria in the internode is enhanced by blue light perceived by the leaves. Planta, 176(2), 277-28.

5. Charles Edwards, D.A. (2018). Light Interception and Plant Growth. Academic Press. 1982.

6. Choi, K.C., Jeong, D.U., Byeon, J.Y., Gu, M., Han, T.H., Koh, G.C., Hwang, I.T., Ki, G.Y., Kim, H.K., Kim, B.S. \& Jung, S.K. (2018). Growth and Flowering of Cut Chrysanthemum as affected by source and time of Light-Emitting Diodes. Philippine Agricultural Scientist, 101(1), 28-35.

7. Demotes-Mainard, S., Péron, T., Corot, A., Bertheloot, J., Le Gourrierec, J., Pelleschi-Travier, S., Crespel, L., Morel, P., Huché-Thélier, L., Boumaza, R. \& Vian, A. (2016). Plant responses to red and far-red lights, applications in horticulture. Environmental and Experimental Botany, Jan 
1,121: 4-21.

8. García-Caparrós, P., Martínez-Ramírez, G., Almansa, E.M., Javier Barbero, F., Chica, R.M. \& Teresa Lao, M. (2020). Growth, Photosynthesis, and Physiological Responses of Ornamental Plants to Complementation with Monochromic or Mixed Red-Blue LEDs for Use in Indoor Environments. Agronomy, 10(2), 284

9. Gómez, C., \& Izzo, L.G. (2018). Increasing efficiency of crop production with LEDs. AIMS Agriculture and Food, 3 (2),135-153.

10. Heo, J., Lee, C., Chakrabarty, D. \& Paek, K. (2002). Growth responses of marigold and salvia bedding plants as affected by monochromic or mixture radiation provided by a light-emitting diode (LED). Plant Growth Regulation, 38 (3), 225-230.

11. Kim, S.J., Hahn, E.J., Heo, J.W., Paek, K.Y. (2004). Effects of LEDs on net photosynthetic rate, growth and leaf stomata of chrysanthemum plantlets in vitro. Scientia Horticulturae, May 3, 101(1-2), 143-51.

12. Lee, Y.I., Fang, W. \& Chen, C.C. (2011). Effect of six different LED light qualities on the seedling growth of Paphiopedilum orchid in vitro. Acta Hort., 907, 389-391.

13. Li, Y., Xin, G., Liu, C., Shi, Q., Yang, F. \& Wei, M. (2020). Effects of red and blue light on leaf anatomy, $\mathrm{CO}_{2}$ assimilation and the photosynthetic electron transport capacity of sweet pepper (Capsicum annuum L.) seedlings. BMC Plant Biology, 20(1):1-6.

14. Monostori, I., Heilmann, M., Kocsy, G., Rakszegi1, M., Ahres1, M., Altenbach, S.B., Szalai, G., Pál, M., Toldi, D., Simon-Sarkadi, L., Harnos, N., Galiba, G., Darko, E. (2018). LED Lighting - Modification of growth, metabolism, yield, and flour composition in wheat by spectral quality and intensity. Frontiers in Plant Science, 9: 1-16.

15. Mortensen, L. \& Stromme, E. (1987). Effects of light quality on some greenhouse crops. Scientia Hort., 33, 27-36.

16. Ouzounis, T., Fretté, X., Rosenqvist, E. \& Ottosen, C.O. (2014). Spectral effects of supplementary lighting on the secondary metabolites in roses, chrysanthemums, and campanulas. J. Plant Physiol., 171, 1491-1499.

17. Oyaert, E., Volckaert, E. \& Debergh, P.C. (1999). Growth of chrysanthemum under coloured plastic films with different light qualities and quantities. Scientia Hort., 79, 195205.

18. Panse, V. G. \& Sukhatme, P. V. (2000). Statistical methods for Agricultural Workers. ICAR. New Delhi.

19. Paradiso, R., \& Proietti, S. (2021). Light-Quality Manipulation to Control Plant Growth and Photomorphogenesis in Greenhouse Horticulture: The State of the Art and the Opportunities of Modern LED Systems. Journal of Plant
Growth Regulation, 1-39.

20. Park, Y. \& Runkle, E.S. (2018). Growing ornamental seedlings under white LEDs. https://www.greenhouseg rower.com/technology/growing-ornamental-seedlings-underwhite-leds/\#Tinsel/143903/4.

21. Park, Y.G. \& Jeong, B.R. (2020). How Supplementary or Night-Interrupting Low-Intensity Blue Light Affects the Flower Induction in Chrysanthemum, a Qualitative ShortDay Plant. Plants, 9(12), 1694.

22. SharathKumar, M., Heuvelink, E., Marcelis, L.F.M. \& van leperen, W. (2021). Floral Induction in the Short-Day Plant Chrysanthemum under Blue and Red Extended LongDays. Frontiers in Plant Science, 11, 1-13.

23. Shen, B.Y., Li, Y.N., Zhao, S.Q., Ding, W.M., Hui, N. \& Li, J. (2014). Effect of dark period lighting regulation on cucumber seedling morphology and comprehensive evaluation analysis and comprehensive evaluation. Nongye Gongcheng Xuebao/Trans. Chin. Soc. Agric. Eng., 30: 201-208.

24. Subburamu, K. \& Ravichandran, V. (2009). Concepts of Crop Physiology, Practical Manual Cum Record, 6-7.

25. Surendra Singh Chauhan. (2017). Studies on Photoperiodic Response in Chrysanthemum morifolium Ramat. Master's Thesis, Indian Agricultural Research Institute. New Delhi.

26. Tamil Nadu Agricultural University Horticultural Crop Production Guide. (2020). TNAU Printing Press, TNAU, Coimbatore.

27. Terfa, M.T., Solhaug, K.A., Gislerød, H.R., Olsen, J.E. \& Torre S. (2013). A high proportion of blue light increases the photosynthesis capacity and leaf formation rate of Rosa $\mathrm{x}$ hybrida but does not affect time to flower opening. Physiol. Plant., 148(1), 146-159.

28. Thakur,T., \& Grewal, H.S. (2016). Grewal Effect of duration of night interruption on growth and flowering of Chrysanthemum cv. Kikiobiory. Journal of Applied and Natural Science, 8 (2): 894 - 898.

29. Urrestarazu, M.G., Bures, S. \& Kotinranta, S. (2018). Artificial Lighting in Agriculture. Technical Article, pp: 1-46.

30. Zhen, S. \& van lersel, M.W. (2017). Far-red light is needed for efficient photochemistry and photosynthesis. J Plant Physiol., 209, 115-122.

31. Zheng, L. \& Van Labeke, M. C. (2017). Long-term effects of red- and blue-light emitting diodes on leaf anatomy and photosynthetic efficiency of three ornamental pot plants. Front. Plant Sci., 8, 1-12.

32. Zheng, L., He, H., \& Song, W. (2019). Application of lightemitting diodes and the effect of light quality on horticultural crops: A review. Hort. Science, 54,1656-1661. 